\title{
Do Poor Citizens Benefit from Mega-Events? São Paulo's Street Vendors and the 2014 FIFA World Cup
}

\section{Calla Hummel}

\begin{abstract}
International mega-events inject millions of dollars into host countries' economies, yet few studies assess which citizens benefit from events and which do not. Governments justify their bids for mega-events by arguing that infrastructure projects, event-related jobs, and tourist spending benefit many citizens. However, researchers find mixed impacts on host economies and the average citizen. Scholars and activists argue that a few businesses benefit while high prices and event-specific laws exclude poor citizens. Under what conditions do poor citizens benefit from mega-events? This article analyzes original interview, survey, and participant observation data on street vendors in São Paulo, Brazil during the 2014 FIFA World Cup. The project finds that most street vendors lost money, while a minority made record profits. Those who benefited from the event used brokers, bribes, and pockets of forbearance to circumvent FIFA's exclusionary rules.
\end{abstract}

Keywords: World Cup, Brazil, informal workers, street vendors, mega-events, brokers, forbearance, corruption

overnments spend billions of dollars to host international mega-events, such as T the FIFA World Cup and the Olympics, and these events affect millions of people. In the buildup to the events, governments justify their bids and budgets by citing the influx of tourists and dollars from the events and long-term benefits from infrastructure projects (Cornelissen et al. 307; Kennelly 2016; Schausteck de Almeida et al. 2015). While governments tout widespread benefits, researchers find that megaevents create significant winners and losers (du Plessis and Maennig 2011, 350). The stakes are high: hundreds of millions of dollars flow into host cities during megaevents, but according to academics, journalists, and activists, poor citizens can lose money and even their livelihoods during these events through eviction and heavy policing (Hedman 2010; Horne and Manzenreiter 2006; Lindell et al. 2010).

Activists and scholars argue that event-specific laws-which increase police powers and prohibit unlicensed commerce, events, and merchandise-prevent poor neighborhoods and small entrepreneurs from benefiting from mega-events (Hedman

Calla Hummel is an assistant professor of political science at the University of Miami. chummel@miami.edu 
2010; Kennelly 2015). These concerns run contrary to government and event booster claims that events create jobs for citizens in the construction and service industries and that infrastructure projects in poor areas improve the quality of life of poorer residents. Under what conditions do poor citizens benefit from mega-events?

This project develops an intensive, mixed-method case study of street vendors' experiences in São Paulo, Brazil around the 2014 FIFA World Cup to investigate why, when, and how poor citizens can benefit from mega-events. Sáo Paulo is similar to other large, global cities that host mega-events. Street vendors are an ideal study population for this project because research on informal workers and mega-events has contrasting ex ante expectations about when and why street vendors benefit. Event boosters and some research on informal workers (De Soto 1989; Holland 2017) would expect pro-poor governments to make concessions to poor citizens and selectively enforce event laws, which would help street vendors benefit from increased economic activity. On the other hand, many mega-event critics would expect that street vendors have few opportunities to benefit when event-specific laws prohibit unofficial events, merchandise, and commerce and increase legal penalties and law enforcement around events (Hedman 2010; Horne and Manzenreiter 2006).

This article argues that poor citizens are more likely to benefit from megaevents when officials who depend on their votes and bribes make event laws inclusive and minimize disruption. Using original interview, survey, and participant observation data, the study finds that street vendors' gains and losses in São Paulo were highly heterogeneous. A small minority of street vendors, allegedly connected by brokers, votes, and bribes to local officials, benefited from selective enforcement of event laws, while most vendors lost money due to disrupted working hours and heavy policing.

This observed variation is explained with the concept of forbearance: "the intentional and revocable nonenforcement of the law" (Holland 2016, 232). The case of street vendors in São Paulo during the 2014 World Cup refines the scope of forbearance. This project and other work on poor citizens in Latin America (Auyero 1999, 2001) suggest that forbearance is conditional on brokers who can bundle poor citizens' claims and resources and then bargain with officials.

The article first reviews existing work on mega-events and the winners and losers that events create. It then uses informal sector research to frame street vendors' experiences during the 2014 World Cup. It analyzes findings from survey data, interviews, and observation. Finally, it outlines the implications for event policy and planning, as well as tentative generalizations to other mega-events and governments. 


\section{Citizens, Mega-Events, AND STRATEGIES}

Mega-events are large, one-time, international cultural, political, or sporting events (Anegger and Herz 2016, 76). Researchers and event planners agree that megaevents involve billions of dollars and affect millions of people (Applebaum 2014; du Plessis and Maennig 2011; Lee and Taylor 2005). Stadiums and public transportation projects move millions of dollars in local economies years before events happen (du Plessis and Maennig 2011; Lee and Taylor 2005; Oms and Velutto 2014), and even the bidding process can spark interest and investment in the tourist industry (Cornelissen and Swart 2010, 108, 110). Host economies and governments can see a significant upside - if authorities manage event budgeting, planning, and spending well (Lee and Taylor 2005, 596). For example, Lee and Taylor (2005) estimate that the 2002 World Cup generated \$307 million in income for the South Korean economy, while Kim et al. $(2006,96)$ find broad social and cultural benefits among residents. However, poor management and budgeting can quickly mire an event in cost overruns and debt. Baade and Matheson (2004a) find that host cities for the 1994 World Cup in the United States ran up $\$ 5.5$ to $\$ 9.3$ billion in losses, despite initial estimates of a $\$ 4.4$ billion profit.

Scholars and promoters disagree on the distribution of benefits from megaevents (Cornelissen et al. 2011; Horne and Manzenreiter 2006; Müller 2017). Du Plessis and Maennig $(2011,350)$ note that every mega-event has winners and losers, whether the event turns an overall profit or not. Event planners, officials, and researchers debate who wins or loses and why. Policymakers and tourism management scholars typically take a sunny view of mega-events and claim that events generate broad and long-lasting benefits for all citizens (Kim et al. 2006). In bidding processes, private and public event boosters always estimate large economic and social benefits for prospective hosts and their citizens (Applebaum 2014; Lee and Taylor 2005). Kim et al. $(2006,88)$ highlight a plethora of studies in tourism management that find positive developmental, reputational, and quality of life impacts for the hosts of mega-events. Tourism management studies suggest that the strength of local budget, planning, and infrastructure management helps explain why some hosts, like Calgary and Seoul, see more positive impacts from mega-events than others, like Athens and Sochi (Kim et al. 2006, 88).

On the other hand, social scientists paint a pessimistic picture of mega-events (Baade and Matheson 2004b; Cornelissen et al. 2011; Kennelly 2016). Du Plessis and Maennig $(2011,350)$ point out that event-related infrastructure spending takes money away from other public services and find that in South Africa in 2010, redirected tax dollars and displaced business hurt taxpayers and many businesses while benefiting a small number of event-related entrepreneurs. Baade and Matheson (2004b) find similar displacement effects and opportunity costs for mega-events in other developing countries, and Baade et al. (2008) estimate similar effects over 25 years of sporting events across Florida. Scholars working with poor populations, such as informal workers and homeless youth, find that governments increase evic- 
tions and local policing before events (Blunden 2012; Hedman 2010; Kennelly 2015). These security measures increase negative and violent interactions between poor citizens and their governments (Kennelly 2016).

Few studies examine which individuals win or lose during mega-events. The ones that do typically conclude that all members of certain categories-homeless people, favela residents, developers, small business owners-win or lose. Scholars rarely ask which citizens within broad social categories benefit during mega-events and why.

Empirically, we know that there is variation in experience within populations. For example, during the World Cup events in Cape Town in 2010, some street vendors and poor residents were evicted while others were not (Hedman 2010); and during the Winter Olympics in Vancouver in 2010, some homeless people left the city while others went to shelters or stayed on the street (Kennelly 2015). This study fills these gaps with a mixed-method case study of street vendors, their interactions with officials, and their business strategies in São Paulo during the 2014 World Cup.

\section{BRIBES, VOTES, AND FORBEARANCE}

Under what conditions to poor citizens benefit from mega-events? This study argues that poor citizens are more likely to benefit from mega-events when officials who depend on their votes and bribes make event laws inclusive and minimize disruption. Officials can adjust laws formally by setting out specific protections, shrinking restricted areas or granting exemptions, or launching temporary vending programs, among other options. More commonly, low-level officials adjust laws informally through selective nonenforcement for specific groups, represented by brokers offering bribes and votes. Poor citizens use multiple strategies to influence their officials: offering electoral support through brokers for forbearance and also offering direct or brokered bribery. This article refines the scope of forbearance (Holland 2016) by suggesting that forbearance is often conditional on brokers who can deliver blocs of votes and bribes to officials.

During the 2014 World Cup, the Brazilian press documented many instances of officials' adjusting formal rules after negotiating with brokers representing organized groups of citizens, as well as instances of informal adjustments through selective nonenforcement. For example, in São Paulo, the press covered contentious negotiations between city officials and street vendor organizations over the boundaries of exclusion zones, as well as the city's formal temporary vending program (Sartorato 2014a, b). During the event, the press also documented heavy enforcement, along with pockets of informal nonenforcement around individual events (Sartorato 2014a).

Research on whether or not poor citizens benefit from mega-events speaks to a decadeslong debate about the conditions under which informal workers profit from government actions. Guha-Khasnobis et al. $(2006,3)$ conceive of informality as a continuum, and this project uses that concept. For the purposes of this project, an informal worker is any person who works at least partially outside of government regula- 
tions. An unlicensed street vendor who does not pay taxes or social security is more informal than a licensed street vendor who keeps receipts but does not pay taxes or social security, but both are informal workers for the purposes of this project. The three demographic categories that this project uses-poor citizen, informal worker, and street vendor-largely overlap. Street vendors are people retailing in public space. In São Paulo, virtually all street vendors are informal workers: most are not authorized to work on the street, and the few that are do not follow tax, social security, and labor regulations (Hummel 2017; Pamplona 2013). Informal workers are not necessarily poor (Peattie 1987), though most are (ILO 2014), and in São Paulo, the vast majority of street vendors qualify as both informal and poor (Pamplona 2013).

One body of work places informal workers on the margins of national economies and political systems (Castells and Portes 1989; Kurtz 2004; Perry 2007). In many places, informal workers are impoverished citizens, cobbling together subsistence from multiple informal, precarious, and temporary income streams, and are largely ignored by the state and large employers (Bhowmik 2012; King and Rueda 2008; Rueda 2007). This literature does not expect event officials to work with poor citizens like street vendors. This research, similar to that of activists and scholars working on event securitization and inequality, would expect mega-event laws and law enforcement to freeze street vendors out of the events (Kennelly 2016; Lindell et al. 2010; Ngonyama 2010).

Another body of work conceives of informal workers as an important voting bloc in many districts and as rational small business owners who choose informality over red tape and excessive regulations (Agarwala 2013; De Soto 1989; Holland 2017). Officials often pay attention to and work with informal workers and their organizations, especially in places where many voters work informally (Auyero 2001; Holland 2015). Agarwala (2013) finds that informal workers make organized appeals to local governments and are successful where pro-poor parties are in power. Holland $(2017,2016,2015)$ finds that officials from pro-poor parties choose not to enforce laws against informal workers and informal settlements in order to shore up their bases. This body of work would expect informal workers to use their flexibility to take advantage of events like the World Cup, and would expect officials who rely on informal workers' votes to alter or forbear on event rules that hurt poor citizens. While Agarwala's and Holland's data come from India, Colombia, Peru, and Chile, the conditions they posit are similar to those in Brazil in 2014: an estimated 24 percent of the adult population worked informally (ILO 2014, 8), under compulsory voting laws virtually all were voters, and the pro-poor Partido do Trabalhadores (Workers' Party) controlled the São Paulo City Hall, as well as the national government. These conditions set the stage for forbearance.

When officials forbear, they intentionally choose not to enforce laws against a specific group or class of people (Holland 2017). When officials do not enforce building codes or public space, tax, or environmental laws, forbearance constitutes a massive subsidy to informal workers and informal settlements (Holland 2016, 233). Holland $(2015,357)$ argues that officials use forbearance to signal to voters that they are pro-poor and to demonstrate that officials from pro-poor parties and 
with poor constituencies forbear, whereas their counterparts representing wealthier constituents do not. Officials use forbearance as an informal, ad hoc welfare system to shore up their electoral support among poor and informal voters (Holland 2017, 7-9). Electoral support comes in the form of votes, as well as participation in campaign activities like canvassing and rallies (Auyero 2001, 1999; Muñoz 2014).

Street vendors and other informal workers offer officials more than votes (Cross 1998). Holland (2016) notes that officials can offer forbearance as a reward for "political behaviors, such as campaign contributions, bribes, votes, or turnout" (235), but also states that "the poor's primary political assets are votes, not money" (235). Anjaria (2011) and Itikawa (2006) find that street vendors in Mumbai and São Paulo, respectively, use bribery to secure their claims to public space. Anjaria $(2011,58)$ argues that street vendors use daily, illicit negotiations with local officials to legitimize their claims to space and their right to vend. Though most street vendors are poor (Bhowmik 2012; Pamplona 2013), they can offer officials large sums as a group: Itikawa (2010a) examined how street vendors in downtown São Paulo maintained their stalls by funneling millions of dollars to Mayor Celso Pitta's reelection slush fund. These cases demonstrate that poor or informal workers routinely influence officials with money, either by bundling many bribes into a considerable sum for one official (Itikawa 2006) or by offering small bribes to low-level officials who can be swayed for less (Anjaria 2011). Where corruption is common, poor citizens may have more frequent opportunities to influence officials with bribes than with votes.

Clearly, this activity is not limited to poor citizens; scandals since the World Cup revealed that FIFA, Brazilian officials, and contactors participated in a massive system of kickbacks (CBS News 2014; Planet FIFA 2016). The FIFA corruption scandals revealed that FIFA officials operated large kickback schemes in practically every country in which they worked and that this activity extended far beyond Brazil (Planet FIFA 2016; Schausteck de Almeida et al. 2015). While wealthier citizens can use a mix of bribes, legal lobbying, and formal campaign contributions to influence high-level officials (Schneider 2004), poorer citizens use electoral support and targeted bribes to lower-level officials, like city council members, and individual streetlevel bureaucrats, like police officers, to secure pockets of forbearance.

Poor citizens often work with brokers, who bundle their votes and bribes and coordinate electoral activities (Auyero 2001, 1999; Hummel 2018). Holland (2015, 366) points to these brokers when discussing street vendors in Bogotá and how street vendor leaders mobilize support and blocs of votes for local politicians who forbear. However, brokers are not part of the concept of forbearance or theories that use the concept. I posit that securing forbearance is often conditional on brokers who can bundle and regularly deliver formidable amounts of electoral support and bribes. This argument rests on the assumption that officials with many constituents prefer to work with powerful individuals and people representing large, organized groups to meeting individually with thousands of unorganized citizens.

In many places, brokers form a necessary intermediate level between poor citizens and officials (Auyero 2001). Brokers can be NGO, union, or association lead- 
ers; well-connected public employees or aides; or community leaders. They must maintain an extensive web of social connections extending deep into a group or community, as well as the local bureaucracy or political parties (Auyero 2001, 94). Brokers specialize in maintaining social connections that other citizens cannot access (Auyero 1999). They greatly simplify officials' jobs by bundling requests, claims, support, votes, and bribes, and they get access to officials that most poor citizens would not otherwise have. Without brokers, local officials do not work with hundreds or thousands of unorganized individuals. For example, unorganized and unlicensed vendors in Sáo Paulo stated in interviews that they want more dialogue with and security from the city government-but without brokers who organize and connect these tens of thousands of vendors, elected officials will not even meet with them.

To summarize, I expect that poor citizens benefit from mega-events when officials who are dependent on their electoral support and their bribes change eventspecific laws to benefit them and to minimize disruption. I expect that brokers are a necessary condition for channeling poor citizens' demands to officials. Where poor citizens do not or cannot work with brokers, I expect that most do not benefit from mega-events, though some may benefit marginally by pursuing individual strategies, like bribing individual police officers. I use the concept of forbearance (Holland 2017, 2016, 2015), research on bribery in informal markets (Anjaria 2011; Itikawa 2010a), and theories of brokers (Auyero 2001, 1999) to explain when and why poor citizens benefit from mega-events and when and why they do not.

\section{Case Selection}

\section{AND RESEARCH METHODS}

To evaluate competing expectations of street vendors' experiences during the World Cup, a team observed activity in street markets, conducted interviews, and administered a survey immediately following the 2014 World Cup. ${ }^{1}$ The survey establishes trends across vendors, and the standardized protocol allows for systematic comparison. The interviews and open-ended survey questions provide descriptions of individuals' experiences and strategies. Observation helps corroborate vendors' selfreports. We visited and observed multiple market areas and events, including a campaign event, and spoke with vendors.

Ideally, we would have surveyed a random sample of licensed and unlicensed vendors and then selected vendors for follow-up interviews. Unfortunately, there is no centralized database of licensed vendors and no viable sampling frame for unlicensed vendors. Therefore we surveyed licensed vendors and solicited open-ended comments, and then used the survey questionnaire to guide interviews with 34 unlicensed vendors. Finally, I followed up with three licensed vendors, three unlicensed vendors, and local researchers in July 2015. ${ }^{2}$ Policy documents and press coverage of policy implementation, events, and World Cup planning committee meetings supplemented observation and street vendors' individual experiences. 


\section{Case Selection}

The project developed a case study of individuals' experiences within one city and one economic sector in order to explain the conditions under which poor citizens benefited from the World Cup. This targeted, subnational case study holds many confounding factors, such as country, government, city, year, event, and occupation, constant (Gerring 2017). We can then compare individuals to explain why some people benefited while others did not.

The 2014 World Cup took place in 12 host cities: São Paulo, Rio de Janeiro, Brasília, Fortaleza, Cuiabá, Manaus, Curitiba, Porto Alegre, Salvador, Recife, Natal, and Belo Horizonte. The FIFA World Cup is one of the few mega-events that takes place in multiple cities, and the 2014 World Cup featured the most host cities ever; FIFA typically caps the number of cities at 10 . São Paulo is a typical case of a megaevent host city. ${ }^{3}$ The city is a large and prosperous but highly unequal metropolis that routinely hosts national and regional cultural, political, and sporting events. Thus, Sáo Paulo is more of a typical case, compared to other events and host cities, than smaller regional hubs, such as Fortaleza, Curitiba, or Cuiabá. São Paulo's regional and national position as a hub and megalopolis is similar to other mega-event host cities around the globe, like Beijing, London, Johannesburg, Sydney, Tokyo, and Seoul, which facilitates cautious generalization to citizens' experiences during other events.

About one hundred thousand people in São Paulo work as street vendors (Itikawa 2010b; Pamplona 2013, 226). Street vending is one of the oldest occupations in the city, and large concentrations of vendors work in the historic central district, as well as in street markets in several peripheral districts (Itikawa 2010b, 248). Brokers work in the larger and more lucrative markets and often run small, geographically bounded street vendor associations (Hummel 2017; Itikawa 2010b, 342-45). Street vending is a common occupation in working-class households (Pamplona 2013, 226), similar to other megalopolises (Bhowmik 2012). Many street vendors are career vendors, while a sizable minority rotates between vending and low-wage formal employment. Pamplona (2013, 237-40) finds that street vendors' demographic data are generally similar to working-class paulistanos' demographic characteristics, though street vendors have below-average educational attainment.

Most street vendors work without a license, while about 1,500 career street vendors have managed to obtain a vending license from the city government. Licensed street vendors work in lucrative market areas and can make a middle-class living. While most street vendors are poor and some are destitute, licenses enable their holders to save and invest, and some licensed vendors own a home or car. ${ }^{4}$ In contrast, unlicensed vendors can spend a third of their workday running from the military police, and make only slightly more than minimum wage (Hummel 2017, 125). Street vendors have flexible business practices, which can enable them to benefit from special events; namely, they can quickly and cheaply change their hours, merchandise, and location to take advantage of one-time opportunities like megaevents. However, vendors also navigate an antagonistic relationship with municipal authorities and law enforcement (Cuvi 2016; Itikawa 2006). 


\section{Interviews}

The research team made a significant effort to interview vendors who fit the range of ages, gender, location, race, and merchandise observed in previous work with street vendors. Interviews were semistructured and based on the survey questionnaire. Most interviewees had only a primary-level education, and they sold a range of goods, from fruit to pirated CDs and DVDs to clothes. The interviewees' demographics are consistent with what I observed on the street: there are a range of ages; more men than women work as unlicensed vendors; and more mestiço and AfroBrazilians work without licenses.

\section{Survey}

The survey took place in July 2014, immediately following the World Cup. The survey covered the main central, western, and eastern market districts of Sáo Paulo. A subset of 85 vendors working in the busiest market received a shorter survey, while 156 vendors received the full survey. In total, surveyors approached 761 stalls, roughly 50 percent of the licensed vendor population in São Paulo, and 241 vendors took the survey. The response rate was 32 percent (additional details and survey instruments are in the online methodological appendix).

The three districts surveyed cover the spectrum of street vending in terms of the socioeconomic characteristics of the neighborhood and the clientele. Licensed vendors in the central commercial zone retail and wholesale a wide range of products for customers from across the city, as well as for buyers from other parts of the country. By contrast, the western district is a working-class residential area on the outskirts of São Paulo, where vendors cater mostly to local residents, and the eastern district is a middle-class residential neighborhood not far from downtown. These three districts contain the main street-vending areas of São Paulo.

\section{Potential Bias}

The licensed vendors in the survey represent the top of the street vendor hierarchy in São Paulo (Cuvi 2016; Itikawa 2010b). Licensed vendors have more job security and more potential for profit than unlicensed vendors because they do not spend part of their workday avoiding the police, they run a much lower risk of loss through confiscation, and their permitted, stationary stalls enable them to store and display much more merchandise than unlicensed, mobile vendors. In other cities in Brazil and around the world, a similar hierarchy exists among licensed and unlicensed vendors, but more vendors hold licenses (Bhowmik 2012; Cross 1998; Holland 2017).

São Paulo's vendor hierarchy potentially biases the project's results toward the experiences of the most privileged vendors. The survey results are likely to overestimate benefits for street vendors in general. I suspect that the interviews with unlicensed vendors are more similar to the experiences of most of the street vendors in Brazil and elsewhere who were not included in the project. Because of this source of 
bias, I do not suggest that the exact distribution of benefits in this study generalizes to street vendors or poor citizens during other mega-events. However, given the expected direction of the bias, I do suggest that only a small minority of poor citizens benefit from mega-events, while most do not.

\section{Special LaWs, Business EfFects, AND ECONOMIC OUTCOMES}

FIFA required Brazil to establish a special legal framework to protect commercial activities during the 2014 World Cup. The legal framework resembled past megaevents legislation. Street vendors experienced the event as a major disruption to their lives and businesses, in part due to event-specific legislation and the accompanying enforcement. The vendors who made profits belonged to organizations politically connected to local officials, whose leaders allegedly brokered forbearance in exchange for electoral support and bribes, as interviews, observation, and secondary sources establish (in particular, see Cuvi 2016 and Itikawa 2006, 2010a).

\section{Lei Geral da Copa}

FIFA, the International Olympic Committee, and other mega-event organizations require host countries to adopt packages of event-specific legislation. FIFA maintains a standard package of legislation that countries are aware of during the bidding process and that FIFA requires hosts to adopt after selection. The FIFA legislation primarily aims to protect commercial rights by explicitly restricting who can profit from the event. These laws can dramatically affect poor citizens' livelihoods; for example, the street vendor NGO Streetnet International estimates that one hundred thousand South African street vendors could not make money during the 2010 World Cup because of clauses in South Africa's World Cup legislation that prohibited street vending (Hedman 2010).

National and local governments have some say in how the laws are implemented. Event laws are drafted and debated in the national legislature before being codified in the host's legal system. In Brazil, the FIFA package passed the national legislature in June 2012 as Law 12.663, which commentators then dubbed the Lei Geral da Copa (General Law of the Cup). It regulated commerce and events around the 2014 World Cup, as well as the 2013 Confederations Cup.

The Lei Geral da Copa included symbolic modifications, such as offering discounted tickets for students, seniors, and federal assistance recipients (chapter 5) and allowing banners on human rights into stadiums (chapter 6). Still, Brazil largely implemented FIFA's standard event package, including exclusive commercial and media rights and heavy law enforcement.

The second and largest chapter of the Lei Geral da Copa was titled "Of the Protection and Exploitation of Commercial Rights." Chapter 2, section 1 of the law established FIFA as a privileged entity with extra protections and expedited copyright and other bureaucratic processes through 2014. Section 2 set out restricted com- 
merce areas and restricted access around official event spaces, where only official sponsors and ticketed participants would be allowed. Section 3 established exclusive media rights for FIFA and its official partners. Section 4 established that FIFA could sue any party that used the Cup to advertise or conduct unofficial commerce around the event, and that Brazilian law enforcement would confiscate and destroy any property used in unofficial media, advertising, or commerce. Chapter 4 placed responsibility on the Brazilian government for all event security, as well as all damages or problems arising from FIFA events. Chapter 7 set out increased penalties of up to one year of detention for making counterfeit FIFA symbols and up to three months for using, storing, or selling them; these penalties were in place through 2014.

An important adjustment to the Lei Geral da Copa concerned street vending prohibitions. The federal law set maximum commercial exclusion zones at two kilometers around event sites but allowed municipal governments to set smaller exclusion parameters. In São Paulo, the city government and street vendor organizations, led by notorious brokers, negotiated smaller exclusion zones that did not overlap with busy market areas (Sartorato 2014b). Licensed street vendors who worked in the smaller exclusion zones were granted exemptions to the zones (unlicensed were not), which minimized event disruption for those vendors. The city government and the local FIFA planning committee also authorized a temporary street vending program in which six hundred vendors would be licensed to sell sponsors' beverages at authorized prices around the event (Sartorato 2014b).

Thus officials marginally adjusted FIFA's event-specific laws to allow some poor citizens to benefit from the event. The adjustments can be understood as limited, clientelistic forbearance (Holland 2016, 235): the Workers' Party introduced half-price tickets for people in federal assistance programs, who are a major component of its electoral base, and the São Paulo city government eased street commerce restrictions for the organized street vendors allied with brokers connected with local officials (Itikawa 2006, 140).

\section{Disruption and Loss}

Street vendors experienced the 2014 World Cup as a major disruption in their daily lives, businesses, and working conditions. Street vendors knew that the 2014 World Cup would be disruptive because they had worked during other World Cups, albeit hosted in other countries and only televised in Brazil. Additionally, many reported in interviews that they had watched police patrols increase in the months before the World Cup and that they knew that the Lei Geral da Copa prohibited vending around the events, prohibited unofficial event-related merchandise, and designated Brazil's game days as national holidays. Street vendors noted that past World Cups hosted in other countries were less disruptive because the televised events affected schedules and consumer behavior but not laws, infrastructure, or policing. During World Cups hosted elsewhere, street vendors could sell event-specific merchandise, such as cheap jerseys, without the threat of heavy policing, event-specific space and commerce regulations, or increased penalties. 
Figure 1. Surveyed Vendors' Change in Income During the World Cup

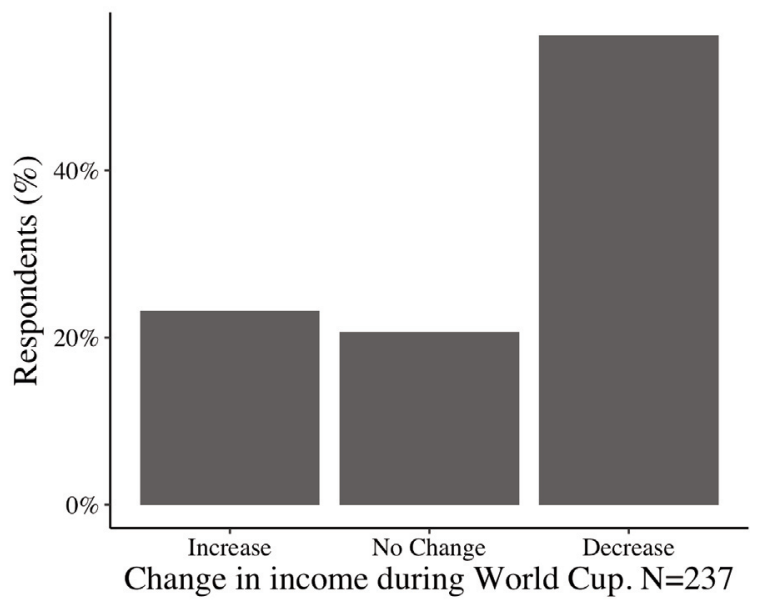

Despite the advance notice, the World Cup changed street vendors' working conditions in major ways that hurt their businesses. One man summed up his experience as, "stress increased but profits fell." Another concluded, "it was a mess, all it did was f- with our lives. It's better not to have a Cup." A CD vendor on a major street reported, "the Cup was bad because everything stopped. Everything closed and everyone went home early, and my sales fell by 50 percent." In another neighborhood, a vendor by a busy subway station explained, "the schedule changed . . . on game days, everyone went home at 2 p.m. I stayed in the street until 4 p.m. and there was no one." 5

For unlicensed vendors, increased police patrols compounded, disrupted, or shortened working hours. One interviewee had his merchandise confiscated twice at the beginning of the World Cup and, with no savings or income for the month, became homeless. Vendors with deeper pockets and less merchandise to lose found increased policing disruptive as well. An unlicensed 65-year-old woman vendor stated, "I'd have four shirts on the ground and they'd [the police] come by and take it. They took my merchandise six times during the Cup." She reported making no money during the month of the event.

Street vendors as a whole saw a decrease in their income during the event, despite a massive increase in the volume of circulating wealth. News reports estimated that the city saw an increase in spending of around one billion reais, hundreds of thousands more than expected (Bonfanti 2014; Jelmayer 2014; Oms and Velutto 2014). However, few street vendors reported windfalls. As figure 1 illustrates, 55 percent of the licensed vendors surveyed reported a drop in their income compared to the previous month. As figure 2 demonstrates, 60 percent of those said their income dropped by 50 percent or more. Twenty-one of the 34 unlicensed interviewees, or 62 percent, reported a decline in earnings. Additionally, both licensed and unlicensed vendors noted that most of their colleagues had also lost money. 
Figure 2. Decline in Income of Surveyed Vendors Who Lost Money

During the World Cup

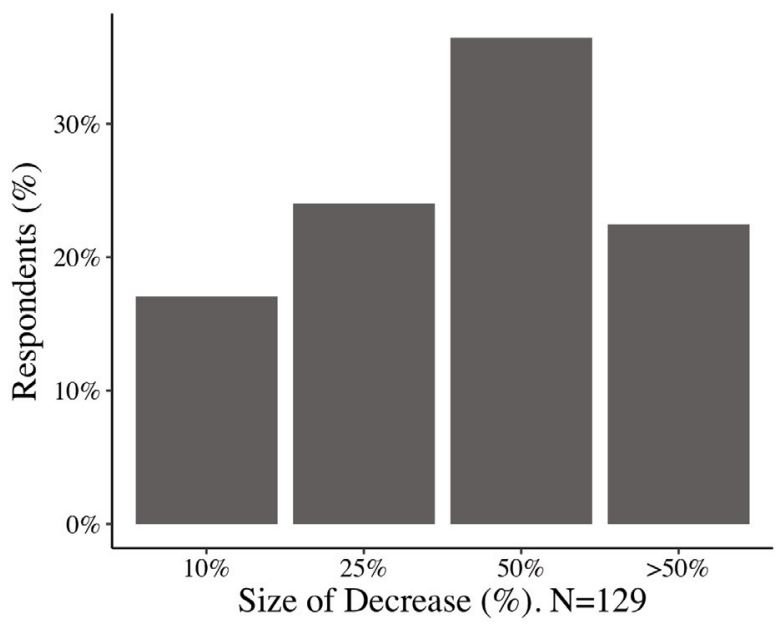

Why did street vendors' incomes drop when hundreds of millions of dollars were flowing into the city's economy? Street vendors attributed their losses to the disruption of the World Cup. They pointed to a steep decrease in foot traffic and drastically shortened working hours. They also explained that potential clients chose to watch games instead of go shopping, which observation during the event corroborated. A vendor who typically sells her wares at outdoor bars noted that people refrained from shopping even when vendors brought their wares to them: "Everyone just looked at the television. I made much less than usual; business fell by half."

Other vendors complained that visitors with high purchasing power, both foreign tourists and wealthy nationals, stayed in high-end areas of the city that have no licensed vendors and a heavy police presence that deters unlicensed vendors. An açaí vendor noted, "foreigners don't pass by to eat açaí. I lost 70 percent." Street vendors reported that when they made sales, the sales were to local customers.

Several licensed vendors reported in unsolicited comments following survey questions that they were in debt because of the World Cup. A licensed street vendor stated that "this Cup left half of the vendors bankrupt." A street artist concurred: "The Cup was horrible. Nothing went to commerce, all of the money went to football. There were many businesses that went bankrupt, restaurants, bakeries that had invested a lot and didn't see a return. Only bars and FIFA made money. I didn't sell anything on game days." These comments suggest that, similar to mega-events in other places (Baade and Matheson 2004a), the 2014 World Cup displaced a significant amount of economic activity and that displacement hurt small local businesses. 


\section{Bribes, Brokers, and Profits}

In São Paulo, individual brokers run small street vendor associations with infrequent meetings and a shifting membership base (Itikawa 2010b, 342-45). The brokers' personalities largely sustain the associations. In interviews, brokers and members stated that they did not have regular meetings or registered members. Instead, members come to the brokers when they have a problem, and the brokers call meetings in the event of marketwide or sectorwide developments. Brokers organize associations geographically and claim to represent vendors in a given market or neighborhood or a specific type of vendor — such as licensed vendors or disabled vendorsin a geographic area (Hummel 2017, 121-22).

Brokers' power lies in their connections to officials and their deep knowledge of how the city works. As one broker stated, "since we work on [public] streets, we need the government. There's a lot of clientelism . . . if you are not connected to a city councilperson, it's difficult." Brokers offer local politicians electoral support, which I saw on display at a large and well-attended campaign rally for a city council member in July 2014 that consisted mostly of street vendors who came with association leaders. However, the forbearance that these brokers periodically secure for their members is extremely limited and does not extend to all street vendors or even all licensed street vendors. One local researcher described how brokers working with the largest association negotiate with the city for their licensed affiliates only and still periodically exclude some licensed members.

A minority of licensed and unlicensed street vendors profited from the World Cup. Of the surveyed vendors, 22 percent experienced an increase. More than half of those who saw their income go up-14 percent of the total sample-reported increases of 50 percent or more, as illustrated in figure 3. The survey recorded merchandise, location, and association membership. ${ }^{6}$ The survey data show that winners were almost exclusively established, licensed vendors with centrally located stalls who had sold World Cup merchandise. We can infer from existing research, survey data, and location that these vendors belong to associations with a wellconnected broker.

Cheap World Cup merchandise was in high demand, but selling it appeared to be risky business at first: the Lei Geral da Copa prohibited unofficial World Cup merchandise, and officials announced that they would crack down on violators (Presidência da República 2012). Virtually none of the flags, noisemakers, footballs, jerseys, and other World Cup merchandise that street vendors sold were legal under the Lei Geral da Copa. Under Brazilian law, street vendors selling merchandise without a license face confiscation but no criminal charges, and licensed street vendors selling merchandise without receipts or authenticating documents risk confiscation and loss of license. The Lei Geral da Copa added fines and one to three months in prison to these penalties.

Despite the official legal framework, I observed many licensed stalls in the busiest markets selling this merchandise in July 2014, and licensed vendors reported that 
Figure 3. Increase in Income of Surveyed Vendors Who Made Money

During the World Cup

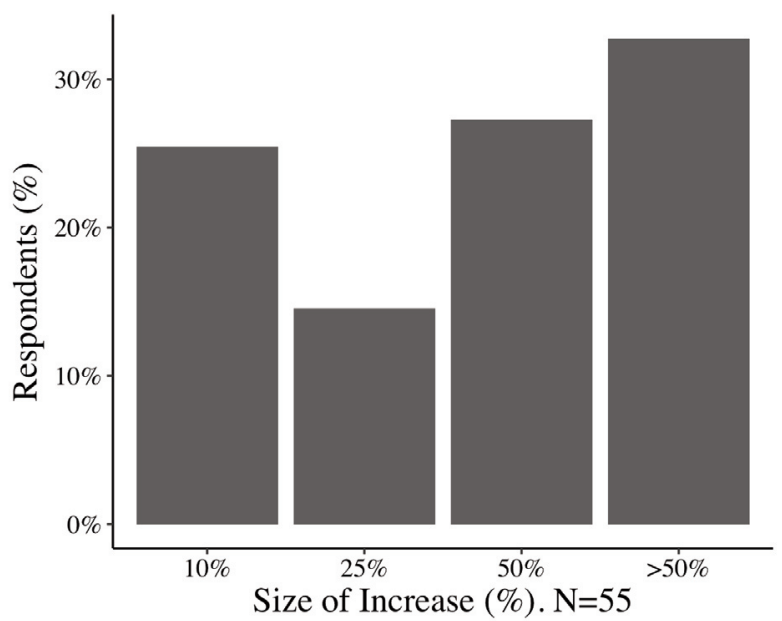

police had not cracked down on their stalls during June or July. Brokers and their organizations in specific markets in the central and western districts surveyed are notorious for exchanging bribes and electoral support with local officials, according to interviewees, local NGO workers, and published research (Cuvi 2016, 405; Itikawa 2006, 2010b). The associations have been implicated in bribery scandals in which leaders funneled millions of dollars in bribes to officials (such as Mayor Pitta's re-election fund) in exchange for a blind eye to illegal business practices (Itikawa 2010a). One researcher explained that more recently, "associations operate with this mafia, corruption, and patronage relationship. Even if the city were controlled by another party, the associations maintain these relationships with [career bureaucrats]. This was a close bribery relationship with the municipality" (personal communication).

Vendors confirmed that they pay bribes to police and local officials in exchange for information. One vendor in a busy location explained, "when I worked at the subway station, I paid a bribe for advance notice [of when the police were coming] ... everyone knows this and everyone pays, even the bars over there pay bribes, everyone has to pay bribes to the auditors. The bars pay the guy who comes by to see how clean the bar is and we pay to get advance notice from the police." A licensed vendor in another busy market area detailed a similar situation and complained about local brokers. "The associations of vendors here are false . . . they all have people inside the district government. You pay them fifty, sixty, twenty reais per day and they take it. Sometimes they give it to the guys inside, they work with them." Another licensed vendor in the same market concurred. "We pay to stay calm, the politicized people make money." In the context of street market politics, "paying to stay calm" means giving money to brokers, bureaucrats, or police for information on which ordinances will be enforced and when, and to ensure that one 
can carry out business without surprise interruptions. "Politicized people" are the leaders and low-level bureaucrats who make money by positioning themselves as brokers in corruption between street vendors and local authorities. ${ }^{7}$

Some unlicensed vendors were also able to turn a profit by selling World Cup merchandise, though their margins were smaller than those of their licensed counterparts. Most unlicensed interviewees did not try to sell World Cup merchandise, often out of fear of the increased police presence and increased penalties. Several of the unlicensed vendors who made money selling World Cup merchandise paid bribes in order to do so. Multiple interviewees reported paying fifty reais to security guards outside the official fan events. The vendors would then get into the event with a backpack full of beer and water to sell to attendees. Vendors reported making one hundred to four hundred reais under this arrangement. For an unlicensed vendor, one hundred reais equates to a decent day's work, and four hundred reais is an exceptional profit under normal vending conditions.

\section{IMPLICATIONS FOR Mega-Event Policy}

This study is among the first to empirically demonstrate that poor citizens' experiences with mega-events are highly heterogeneous. The project establishes this finding with original quantitative and qualitative evidence. While most people in this study did not benefit from the World Cup, both quantitative and qualitative data indicate a wide variation in individual experiences.

The study's small group of winners and big group of losers suggest that the World Cup may have increased differentiation and inequality between well-connected, licensed vendors and the rest of the sector. If this is the case, mega-events like the World Cup could reinforce or calcify local hierarchies instead of providing widespread opportunities to small entrepreneurs and innovators. Unfortunately, the survey did not ask questions about inequality among vendors. Future research on mega-events should evaluate whether the events exacerbate existing inequality or increase differentiation.

In July 2015, a year after the main study, I followed up with a half-dozen licensed and unlicensed study participants. Most had lost small amounts of money during the 2014 World Cup. By July 2015, these half-dozen participants had psychologically moved on, and the Cup was a distant memory. Their experiences suggest that the negative impacts of mega-events may be relatively short-lived. However, Cuvi $(2016,404,410)$ found that when the São Paulo city government revoked vending licenses in 2012, many of the hardest-hit vendors disappeared from markets. This finding cautions that the ad hoc follow-up may not have recorded long-term negative effects if the most affected vendors left street vending.

This project suggests that when mega-events move into a city without taking the structure of the population into account, the event will hurt many poor citizens, as it did in São Paulo in 2014, as well as in Cape Town during the 2010 World Cup and in Vancouver during the 2010 Winter Olympics (Kennelly 2015; Lindell et al. 
2010). This outcome is not inevitable. Mega-event planning committees can and should include poor or working-class representatives. Where possible, these representatives should be elected by members of existing organizations like street vendor associations.

Mega-events should have more programs that directly enroll residents in ways that benefit them. However, these programs should be far-reaching, routine, and institutionalized, not hastily planned compromises. To benefit poor citizens, enrollment in these programs should try to bypass local hierarchies. One way to do this would be to use a lottery system or prioritize enrollment for people with an easily obtainable measure of need, like enrollment in a public assistance program.

The project further recommends that mega-events relax restrictions around events, especially restrictions on unofficial merchandise and street commerce near events. Most of the World Cup merchandise that street vendors sold in São Paulo would have been legal under Brazilian law. The merchandise was not counterfeitmost of the merchandise that I observed consisted of simple jerseys, flags, and toys in the Brazilian team's yellow and green colors that bore no brand name or tagbut it was illegal under the Lei Geral da Copa because it lacked the FIFA logo and did not pay accompanying royalties. Only a few stalls sold counterfeit jerseys that copied the design and logos of the official suppliers. Ironically, this was because the counterfeits were higher in quality and more expensive to buy wholesale while the unbranded green and yellow merchandise was cheap to buy and easy to sell. This case study suggests that the Lei Geral da Copa did not stop unofficial commerce and may have fueled petty corruption. Exclusionary event laws may continue to fuel petty corruption during future mega-events.

For example, the Russian World Cup Law (Federal Law 108-FZ) includes FIFA-directed provisions similar to those in past World Cups, such as exclusive licensing rights, tax breaks, and the two-kilometer commercial exclusion zones around events like those that evicted South African vendors in 2010 and led Brazilian vendors to bribe security personnel in 2014 (Hedman 2010; Müller 2017, 1126). However, the Russian World Cup Law goes beyond past legislation: it also suspends labor protections and fast-track expropriations and prohibits protest (Müller 2017, 1127).

Scholars and NGO investigators suspect that rampant corruption accounted for as much as two-thirds of Russia's cost overruns (Melnaes 2017; Müller 2017, 1124), and economists expect the World Cup to be a steep net loss for Russia (de Nooij et al. 2011, 541). This project expects that exclusionary laws like the Russian World Cup Law put local businesses and residents at risk of bankruptcy and arrest. Additionally, this project's findings suggest that the 2018 World Cup could have involved historic levels of corruption, as elites hid kickbacks in cost overruns and small businesspeople bribed authorities for access to the event and exemptions from crackdowns. 


\section{CONCLUSIONS}

This study argues that the key to whether poor citizens benefit during mega-events or not rests in the hands of officials who create and implement event-specific policies. Where officials are dependent on poor citizens' votes or bribes, they can adjust event regulations to allow at least some poor citizens to benefit. This project suggests that this is more likely where brokers represent and negotiate for large numbers of poor citizens. In São Paulo, brokers enabled connected street vendors to benefit from the World Cup. Outside of mega-events, brokers provide access to officials for routine, day-to-day interactions between the city and street vendors. This project suggests that their role is particularly important in the face of new special interests. Events like the World Cup empower new special interests, as do shocks and crises. Skillful brokers can blunt or redirect the effects of countervailing special interests away from the people the brokers represent.

In the case of the 2014 World Cup, FIFA and its associates were powerful special interests, set to remake relationships between the city and vendors, at least temporarily. For example, the original two-kilometer exclusion zone would have put hundreds of street vendors out of work for over a month, but brokers intervened with officials to renegotiate a zone that did not include their affiliates. People outside of the brokers' networks then bore the brunt of the effects, as the unlicensed individual vendors who normally sell around event areas experienced near-constant policing during the World Cup.

Brokers rarely act out of magnanimity; they exchange favors or charge fees for their work (Auyero 2001; Hummel 2018). Brokers represent and channel benefits to people who can compensate them with economic or social resources; they do not usually work with the most destitute. This project suggests that without a dramatic overhaul in event-specific regulations, at best only a small minority of poor citizens benefit from mega-events, while most do not.

São Paulo should have been a relatively easy case in which to find widespread benefits for poor citizens. First, tourist spending was more than 300 million reais higher than expected (Oms and Velutto 2014). Second, street vending is a large and established profession in the city; many street vendors are highly experienced vendors who have profited from other World Cups and mega-events. Additionally, some vendors have longstanding ties to powerful local bureaucrats and politicians. Finally, the national Workers' Party government's planning included benefits for marginal populations, such as infrastructure improvements in peripheral areas. In short, most street vendors in the study experienced losses even under better than expected conditions. Poor citizens in Brazil stood a better chance of benefiting from the 2014 World Cup than, for example, those in South Africa during the 2010 World Cup or those in Russia during the 2018 World Cup.

The minority of street vendors who benefited from the event profited from limited and highly contingent pockets of forbearance and used semilegal or illicit strategies. The leaders of politically connected street vendor organizations negotiated lim- 
ited forbearance on the commercial exclusion zone policy for their members (Sartorato 2014a). A number of unlicensed vendors bribed security forces to get access to event spaces where street vending was prohibited.

To host the 2014 World Cup, Brazil spent an estimated 14 billion U.S. dollars. According to government figures, about one million foreigners visited the country during the tournament (Marcopoto 2014). The São Paulo city government reported one billion reais, or 355 million dollars, in tourist spending in the month of the Cup (Oms and Velutto 2014). Major stakeholders_including FIFA—made a lot of money. In the years since the event, investigations have found that individual FIFA representatives, construction executives, and politicians also pocketed hundreds of millions in bribes and kickbacks (Planet FIFA 2016). Despite high profits for insiders and official event partners, this project found that most street vendors did not benefit from the World Cup, due to exclusion and disruption.

\section{NOTES}

I acknowledge the invaluable input of the editors and three anonymous reviewers, as well as Bethany Albertson, Javier Auyero, Jacinto Cuvi, Rodolfo Disi-Pavlic, Dana El-Kurd, Eva Hershaw, Alisha Holland, Luciana Itikawa, Stephen Jessee, Raúl Madrid, Rosana Pinheiro-Machado, Sally Roever, Amanda Skuldt, Andy Stravers, Mike Touchton, and the street vendors who participated in this project. This material is based on work supported by the National Science Foundation Graduate Research Fellowship number 2013163892. All errors are my own.

1. I collaborated on data collection with a scholar in a different field who works with the same population but asks different questions; analyses and manuscripts were completed separately.

2. I contacted the few participants who, after an interview or postsurvey conversation, had given me their contact information. Thus, the follow-up did not follow any kind of systematic study protocols.

3. For a typology of case studies and selection criteria for the typical case subtype, see Gerring and Seawright 2008, 297; Gerring 2017.

4. The street vendors I have worked with corroborate Pamplona's findings: on average, most make about minimum wage and have low educational attainment. Those averages come from a wider distribution of experiences, assets, and attainment. Of the licensed and unlicensed street vendors I have worked with, most cluster tightly around those averages, with some outliers. With regard to assets, a few, mostly unlicensed vendors are destitute, while a few, mostly licensed vendors are middle class. However, even the most successful vendors I know are far from wealthy: they own a small apartment in central Sáo Paulo or a self-constructed house in a distant neighborhood. They may own a used car. The range of education is broader and correlates with age: while some older vendors are illiterate and most did not finish high school, most younger vendors finished high school and some are in college.

5. Game days refer to both the days that the Brazilian team played, which were national holidays, and days when the São Paulo stadium hosted a game, which snarled the city's infrastructure.

6. We asked about organizational membership for all vendors except those in a two-byfour-block area, who, we know from previous research, all belong to one tightly controlled association under one particularly powerful broker. 
7. These arrangements are common in street markets elsewhere as well. For examples of similar systems in Indian and Bolivian street markets, respectively, see Anjaria 2011; Hummel 2018.

\section{REFERENCES}

Agarwala, Rina. 2013. Informal Labor, Formal Politics, and Dignified Discontent in India. Cambridge: Cambridge University Press.

Anjaria, Jonathan Shapiro. 2011. Ordinary States: Everyday Corruption and the Politics of Space in Mumbai. American Ethnologist 38, 1: 58-72.

Applebaum, Binyamin. 2014. If You Build It... New York Times, August 10, 14.

Arnegger, Julius, and Marc Herz. 2016. Economic and Destination Image Impacts of MegaEvents in Emerging Tourist Destinations. Journal of Destination Marketing and Management 5, 2: 76-85.

Auyero, Javier. 1999. From the Client's Point(s) of View: How Poor People Perceive and Evaluate Political Clientelism. Theory and Society 28, 2: 297-334.

- 2001. Poor People's Politics: Peronist Survival Networks and the Legacy of Evita. Durham: Duke University Press.

Baade, Robert A., and Victor A. Matheson. 2004a. The Quest for the Cup: Assessing the Economic Impact of the World Cup. Regional Studies 38, 4: 343-54.

2004b. Mega Sporting Events in Developing Nations: Playing the Way to Prosperity? South African Journal of Economics 72, 5: 1085-96.

Baade, Robert A., Robert Baumann, and Victor A. Matheson. 2008. Selling the Game: Estimating the Economic Impact of Professional Sports Through Taxable Sales. Southern Economic Journal 74, 3: 794-810.

Bhowmik, Sharit, ed. 2012 (2010). Street Vendors in the Global Urban Economy. Lanham: Taylor and Francis.

Blunden, Hazel. 2012. The Olympic Games and Housing. In The Palgrave Handbook of Olympic Studies, ed. Helen Jefferson Lenskyj and Stephen Wagg. Basingstoke: Palgrave Macmillan. 520-32.

Bonfanti, Cristiane. 2014. Com a copa, turistas estrangeiros gastaram US\$ 797 milhōes no brasil em junho. $O$ Globo, July 25. https://oglobo.globo.com/economia/com-copaturistas-estrangeiros-gastaram-us-797-milhoes-no-brasil-em-junho-13376345

Castells, Manuel, and Alejandro Portes. 1989. World Underneath: The Origins, Dynamics, and Effects of the Informal Economy. In The Informal Economy: Studies in Advanced and Less Developed Countries, ed. Portes, Castells, and Lauren A. Benton. Baltimore: Johns Hopkins University Press. 11-40.

CBS News. 2014. World Cup 2014 Construction in Brazil Marred by Corruption, Waste. May 12. https://www.cbsnews.com/news/world-cup-2014-construction-in-brazilmarred-by-corruption-waste

Cornelissen, Scarlett, and Kamilla Swart. 2006. The 2010 Football World Cup as a Political Construct: The Challenge of Making Good on an African Promise. Sociological Review 54, 2: 108-23.

Cornelissen, Scarlett, Urmilla Bob, and Kamilla Swart. 2011. Towards Redefining the Concept of Legacy in Relation to Sport Mega-Events: Insights from the 2010 FIFA World Cup. Development Southern Africa 28, 3: 307-18.

Cross, John Christopher. 1998. Informal Politics: Street Vendors and the State in Mexico City. Stanford: Stanford University Press. 
Cuvi, Jacinto. 2016. The Politics of Field Destruction and the Survival of São Paulo's Street Vendors. Social Problems 63, 3: 395-412.

De Soto, Hernando. 1989. The Other Path: The Invisible Revolution in the Third World. New York: Harper and Row.

Du Plessis, Stan, and Wolfgang Maennig. 2011. The 2010 FIFA World Cup High-Frequency Data Economics: Effects on International Tourism and Awareness for South Africa. Development Southern Africa 28, 3: 349-65.

Gerring, John. 2017. Case Study Research: Principles and Practices. 2nd ed. Cambridge: Cambridge University Press.

Guha-Khasnobis, Basudeb, Ravi Kanbur, and Elinor Ostrom. 2006. Beyond Formality and Informality. In Linking the Formal and Informal Economy: Concepts and Policies, ed. Guha-Khasnobis, Kanbur, and Ostrom. New York: Oxford University Press. 1-18.

Hedman, Maria. 2010. This World Cup Is Not for Us Poor People: Interviews with Street Vendors in Port Elizabeth and Pretoria, South Africa. Durban: Streetnet International.

Holland, Alisha C. 2015. The Distributive Politics of Enforcement. American Journal of Political Science 59, 2: 357-71.

. 2016. Forbearance. American Political Science Review 110, 2: 232-46.

-2017. Forbearance as Redistribution: The Politics of Informal Welfare in Latin America. Cambridge: Cambridge University Press.

Horne, John, and Wolfram Manzenreiter. 2006. An Introduction to the Sociology of Sports Mega Events. Sociological Review 54, 2: 1-24.

Hummel, Calla. 2017. Disobedient Markets: Street Vendors, Enforcement, and State Intervention in Collective Action. Ph.D. diss., University of Texas, Austin.

- 2018. Bribery Cartels: Collusive Corruption in Bolivian Street Markets. Latin American Research Review 53, 2: 217-30. DOI: doi.org/10.25222/larr.342

International Labor Organization (ILO). 2014. Women and Men in the Informal Economy: A Statistical Picture. 2nd ed. Geneva: ILO.

Itikawa, Luciana. 2006. Vulnerabilidades do trabalho informal de rua. São Paulo em Perspectiva 20, 1: 136-47.

- 2010a. Clandestine Geometries: Mapping Street Vending in Downtown São Paulo. In Street Vendors in the Global Urban Economy, ed. Sharit K. Bhowmik. New Delhi: Routledge. 256-74.

- 2010b. Trabalho informal nos espaços públicos no centro de São Paulo. Doctoral thesis, Universidade de São Paulo.

Jelmayer, Rogerio. 2014. Brazil Tourists Seen Spending \$2.97 Billion During World Cup. Wall Street Journal, June 17. www.wsj.com/articles/brazil-tourists-seen-spending-2-97billion-during-world-cup-1403010185

Kennelly, Jacqueline. 2015. "You're Making Our City Look Bad": Olympic Security, Neoliberal Urbanization, and Homeless Youth. Ethnography 16, 1: 3-24.

- 2016. Olympic Exclusions: Youth, Poverty and Social Legacies. London: Routledge.

Kim, Hyun Jeong, Dogan Gursoy, and Soo-Bum Lee. 2006. The Impact of the 2002 World Cup on South Korea: Comparisons of Pre- and Post-Games. Tourism Management 27, 1: 86-96.

King, Desmond, and David Rueda. 2008. Cheap Labor: The New Politics of Bread and Roses in Industrial Democracies. Perspectives on Politics 6, 2: 279-97.

Kurtz, Marcus J. 2004. The Dilemmas of Democracy in the Open Economy: Lessons from Latin America. World Politics 56, 2: 262-302. 
Lee, Choong-Ki, and Tracy Taylor. 2005. Critical Reflections on the Economic Impact Assessment of a Mega-Event: The Case of 2002 FIFA World Cup. Tourism Management 26, 4: 595-603.

Lindell, Ilda, Maria Hedman, and Kyle-Nathan Verboomen. 2010. The World Cup 2010 and the Urban Poor: World Class Cities for All? Nordic Policy Institute Policy Notes. https://www.files.ethz.ch/isn/121748/2010_5.pdf

Marcopoto, Talia. 2014. Brazil Claims "Victory" in World Cup. CNN, July 16. edition.cnn.com/2014/07/16/travel/brazil-world-cup-tourism

Melnaes, Håvard. 2017. The Slaves of St. Petersburg. Trans. Lars Johnsen. Josimar. www.josimar.no/artikler/the-slaves-of-st-petersburg/3851

Müller, Martin. 2017. How Mega-Events Capture Their Hosts: Event Seizure and the World Cup 2018 in Russia. Urban Geography 38, 8: 1113-32.

Muñoz, Paula. 2014. An Informational Theory of Campaign Clientelism: The Case of Peru. Comparative Politics 47, 1: 79-98.

Ngonyama, Percy. 2010. The 2010 FIFA World Cup: Critical Voices from Below. Soccer and Society 11, 1-2: 168-80.

Nooij, Michiel De, Marcel Van Den Berg, and Carl Koopmans. 2013. Bread or Games? A Social Cost-Benefit Analysis of the World Cup Bid of the Netherlands and the Winning Russian Bid. Journal of Sports Economics 14, 5: 521-45.

Oms, Carolina, and Luciele Velluto. 2014. A copa que brasil ganhou. Istoe Dinheiro, July 7. www.istoedinheiro.com.br/noticias/negocios/20140711/copa-que-brasilganhou/170887.shtml

Pamplona, João Batista. 2013. Mercado de trabalho, informalidade e comércio ambulante em São Paulo. Revista Brasileira de Estudos de Populacão 30, 1: 225-49.

Peattie, Lisa. 1987. An Idea in Good Currency and How It Grew: The Informal Sector. World Development 15, 7: 851-60.

Perry, Guillermo, ed. 2007. Informality: Exit and Exclusion. Washington, DC: World Bank.

Planet FIFA. 2016. Film. Directed by Jen Louise Perez. Netflix.

Presidência da República. 2012. Lei n. 12.663 de 5 de Junho de 2012. www.planalto. gov.br/ccivil_03/_ato2011-2014/2012/lei/112663.htm

Rueda, David. 2007. Social Democracy Inside Out: Partisanship and Labor Market Policy in Advanced Industrialized Democracies. Oxford: Oxford University Press.

Sartorato, Diego. 2014a. Prefeitura de SP define áreas que barram comerciantes da rua em eventos FIFA. Rede Brasil Atual, April 10. www.redebrasilatual.com.br/politica/ 2014/04/prefeitura-define-areas-de-exclusao-em-eventos-da-fifa-para-barrar-comerciantesde-rua-2568.html

— 2014b. São Paulo libera 2,4 mil ambulantes para a Copa. Cerveja sairá pela metade do preço. Rede Brasil Atual, June 2. www.redebrasilatual.com.br/trabalho/2014/06/saopaulo-libera-2-4-mil-ambulantes-para-a-copa-na-rua-cerveja-saira-pela-metade-dopreco-7111.html

Schausteck de Almeida, Bárbara, Chris Bolsmann, Wanderley Marchi Junior, and Juliano de Souza. 2015. Rationales, Rhetoric and Realities: FIFA's World Cup in South Africa 2010 and Brazil 2014. International Review for the Sociology of Sport 50, 3: 265-82.

Schneider, Ben Ross. 2004. Business Politics and the State in Twentieth-Century Latin America. Cambridge: Cambridge University Press.

Seawright, Jason, and John Gerring. 2008. Case Selection Techniques in Case Study Research: A Menu of Qualitative and Quantitative Options. Political Research Quarterly 61, 2: 294-308. 


\section{SUPPORTING INFORMATION}

Additional supporting materials may be found with the online version of this article at the publisher's website: Methodological Appendix 